\title{
Optimalisasi E-Report Utilities Shift Supervisor untuk Meningkatkan Kinerja Operasional
}

\author{
Gellysa Urva ${ }^{1}$, Syahrul Ramadhani² \\ 1) Program Studi Teknik Informatika, Sekolah Tinggi Teknologi Dumai \\ Jl. Utama Karya Bukit Batrem II \\ Email: gellysa.urva@gsmail.com
}

\begin{abstract}
ABSTRAK
Proses industri perlu memperhatikan kegiatan operasional berjalan dengan lancar. Untuk memastikan kinerja kegiatan operasional sudah berjalan baik maka diperlukan laporan operasional yang dibuat oleh pengawas lapangan. Laporan operasional saat ini masih menggunakan buku yang nantinya akan di berikan setiap bulannya. Permasalahan yang muncul adalah pimpinan harus menghubungi pengawas lapangan atau datang langsung untuk mendapatkan informasi. Pencarian Informasi seperti ini menjadi tidak efektif dan efisien. E-Report atau Laporan Elektronik menjadi solusi atas permasalahan yang terjadi. Metodologi penelitian menggunakan metodologi berorientasi objek untuk tahapan analisa dan perancangannya dan alat bantu yang digunakan menggunakan Diagram Unifield Modeling Language (UML). Dengan adanaya E-Report ini sangat mendukung peningkatan kinerja operasional, pengolahan data yang tadinya masih menggunakan sistem manual menjadi lebih optimal dengan sistem yang terkomputerisasi sehingga informasi yang dihasilkan dapat diakses lebih efektif dan efisien.
\end{abstract}

Kata Kunci: Optimalisasi, E-Report, Kinerja

\begin{abstract}
Industrial processes need to pay attention to operational activities running smoothly. To ensure the performance of operational activities is running well, it is necessary to have an operational report prepared by the field supervisor. Operational reports are currently still using a book which will be provided every month. The problem that arises is that the leader must contact the field supervisor or come directly to get information. Information search like this becomes ineffective and inefficient. E-Report or Electronic Report is a solution to the problems that occur. The research methodology uses an object-oriented methodology for the analysis and design stages, and the tools used use the Unifield Modeling Language (UML) Diagram. With this E-Report, it really supports improving operational performance, data processing that was previously still using a manual system becomes more optimal with a computerized system so that the resulting information can be accessed more effectively and efficiently.
\end{abstract}

Keywords : Optimization, E-Report, Performance 


\section{Pendahuluan}

Utilities Unit Production merupakan salah satu bagian dari Refinery Unit II Production Dumai yang berfungsi menyediakan supply air, uap, udara, dan listrik untuk keperluan kegiatan produksi. Berdasarkan fungsi tersebut maka Utilities Unit Production harus memastikan kegiatan operasional berjalan dengan baik. Untuk memastikan kegiatan operasional sudah berjalan baik maka diperlukan laporan operasional. Laporan operasional yang dibuat oleh pengawas lapangan berisikan informasi yang akan diberikan kepada pimpinan. Dengan laporan tersebut pimpinan mengetahui kondisi operasional dan kendala apa yang terjadi dilapangan, sehingga pimpinan dapat mengambil kebijakan dan menghubungi pihak terkait untuk dilakukannya maintenance. Laporan operasional saat ini masih menggunakan buku yang nantinya akan di berikan setiap bulannya. Permasalahan yang muncul adalah pimpinan harus menghubungi pengawas lapangan atau datang langsung untuk mendapatkan informasi. Informasi seperti ini menjadi tidak efektif dan efisien. Mengingat kendala-kendala tersebut perlu dilakukan tindakan supaya kegiatan operasional perusahaan tidak terganggu. Selain itu, permasalahan yang sering terjadi adalah informasi yang sifatnya tidak urgent membuat tindakan maintenance menjadi terhambat pengerjaannya dikarenakan pimpinan tidak mengetahui informasi tersebut. Akibatnya peralatan menjadi terbengkalai tanpa dilakukan perbaikan. Sehingga ini akan membuat operasional perusahaan tidak optimal jika sewaktu-waktu peralatan tersebut diperlukan.

Penelitian yang dilakukan Rachmawati dkk tentang Optimalisasi sistem informasi perjalanan dinas menyatakan Optimalisasi suatu sistem dibutuhkan guna meningkatkan kejelasan informasi yang detail dan memenuhi kebutuhan operasional yang transparansi (Rachmawati, Retnasari, \& Rachmawati, 2018). Penelitian terkait dengan system informasi juga dilakukan oleh (Khairatunnisa, 2021) dengan judul system informasi donor darah pada unit transfuse darah palang merah Indonesia kota Dumai berbasis web. Sumber informasi untuk pengambilan keputusan manajemen bisa didapatkan dari informasi eksternal dan informasi internal yang prosesnya membutuhkan waktu yang cepat. (Rahardja, Aini, \& Enay, 2017). Suatu aplikasi business intelligence yang dapat melakukan analisis data dan memberikan laporan secara otomatis dalam bentuk dashboard reporting yang dapat memberikan informasi berupa pengetahuan untuk menanggulangi kurangnya report penjualan dari sistem informasi distibusi mendukung kinerja suatu perusahaan.(Hakim, Fitriani, Algoritma, Tinggi, \& Garut, 2013). Melalui Sistem informasi E-document proses penyimpanan menjadi lebih efektif, sehingga pencarian surat masuk dan surat keluar lebih cepat dan meminimalisir kerusakan atau kehilangan data (Gatam, 2015)

Mengingat pentingnya aset tetap bagi suatu organisasi, maka diperlukan pengelolaan aset tetap. Manajemen aset adalah proses pengelolaan, perencanaan, dan pengendalian perolehan, penggunaan, pemeliharaan, perbaikan, atau pelepasan aset berwujud (aset tetap) untuk mengoptimalkan potensi penggunaannya dan untuk meminimalkan risiko dan biaya terkait selama masa manfaatnya dengan menggunakan aset tidak berwujud seperti aplikasi pendukung, pengambilan keputusan dan proses bisnis. Sehingga diperlukan laporan operasional yang 
elektronik guna pendataan aset di Dinas Perkebunan Aceh. (Sadharma, 2021). EGovernment merupakan merupakan upaya untuk upaya untuk mengembangkan penyelenggaraan kepemerintahan yang berbasis (menggunakan) elektronik dalam rangka meningkatkan kualitas layanan publik secara efektif dan efisien. Aplikasi ini dibuat untuk menjadi sarana informasi yang cepat dan efektif antara masyarakat dengan pemerintah. (Mambu, Informatika, Sam, \& Manado, 2016)

Diharapkan degan adanya E-Report ini dapat memudahkan dalam memberikan laporan secara otomatis dan menyeluruh serta dengan cepat mengetahui kondisi operasional dimanapun dan kapanpun tanpa harus menghubungi pengawas lapangan atau datang langsung ke lapangan. Mengingat cakupan yang luas mengenai sistem laporan pada bagian Utilities Unit Production, penulis hanya akan membahas laporan operasional Shift Supervisor. Tidak membahas tindakan apa yang dilakukan selanjutnya.

\section{Metode Penelitian}

Metode penelitian yang digunakan dalam penelitian ini menggunakan Metode Waterfall yaitu metode pengembangan suatu sistem informasi yang diterapkan secara sistematik dan sekuensia. (Caesar, Hanif, \& Pakereng, 2021). Adapun langkah-langkah dari metode penelitian sebagai berikut :

1. Memahami Permasalahan

Pada tahapan ini, untuk memahami permasalahan yang dihadapi dengan melakukan wawancara langsung kepada narasumber yang berkaitan dalam pembuatan Laporan Operasional.

2. Mempelajari Proses Pembuatan Laporan Operasional

Pada tahapan ini, melalui proses wawancara untuk mengetahui proses pembuatan laporan operasional dari sistem penginputan data sampai output yang dikeluarkan yang ada pada PT. Pertamina (Persero) RU II Dumai, sehingga diketahui gambaran sistem secara keseluruhan.

3. Analisa Sistem

Analisa sistem berjalan menggunakan Diagram Unified Modelling Language (UML) dengan menggunakan Usecase Diagram, Activity Diagram, Squence Diagram, dan Class Diagram. (Urva \& Sellyana, 2018)

4. Perancangan Sistem

Pada tahapan ini, akan dirancang sistem usulan berdasarkan analisa sistem yang sudah dilakukan dengan membuat perancangan User Interface yang sesuai dengan kebutuhan sistem dan menggambarkan hubungan antara satu class dengan class yang lainnya (hubungan antara satu objek dengan objek yang lain) dengan menggunakan Class Diagram (Entity Class).(Urva \& Manalu, 2021)

5. Pengujian Sistem

Pada tahapan ini dilakukan pengujian terhadap sistem usulan untuk memastikan sistem sudah memenuhi kebutuhan yang sudah ditentukan. 
Unitek : Jurnal Universal Teknologi

Vol.14 No.2 Juli - Desember 2021

e-ISSN : 2580-2582, p-ISSN: 2089-3957

\section{Hasil dan Pembahasan}

\section{Rancangan Sistem}

Proses pembuatan Laporan Operasional Utilities Shift Supervisor di PT. Pertamina (Persero) RU II Dumai digambarkan dengan menggunakan UML yaitu Use Case Diagram, Activity Diagram, Squence Diagram, dan Class Diagram. Adapaun Activity Diagram untuk masing-masing pembuatan laporan dapat dilihat pada gambar dibawah ini :

a. Use Case Diagram

Usecase atau diagram usecase merupakan permodelan untuk kelakuan ( behavior ) sistem informasi yang akan dibuat. Adapun usecase diagram untuk Sistem Informasi Laporan Operasional Utilities Shift Supervisor sebagai berikut :

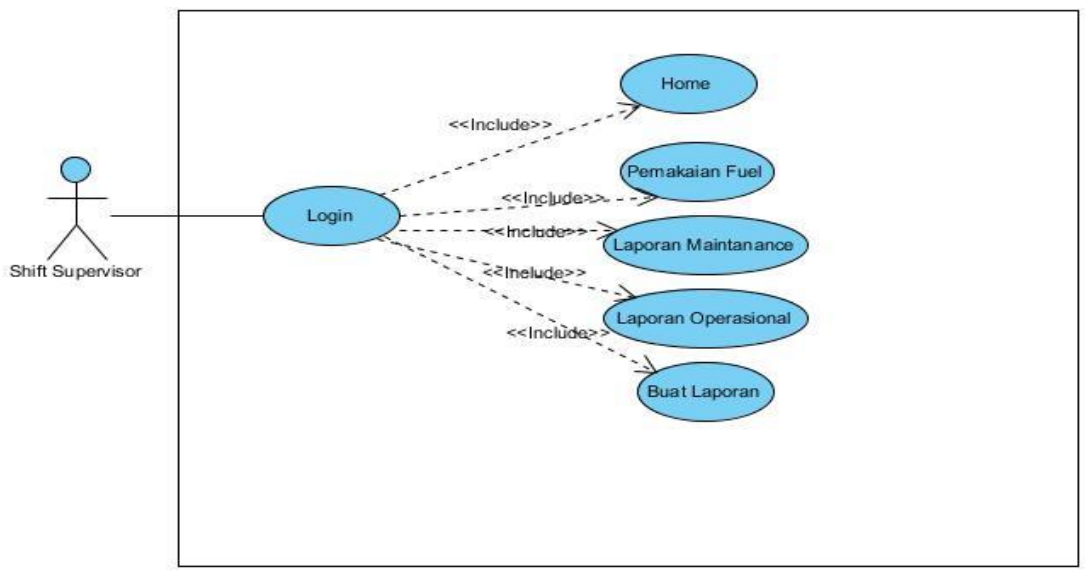

Gambar 1. Squence Diagram Login Shift Supervisor

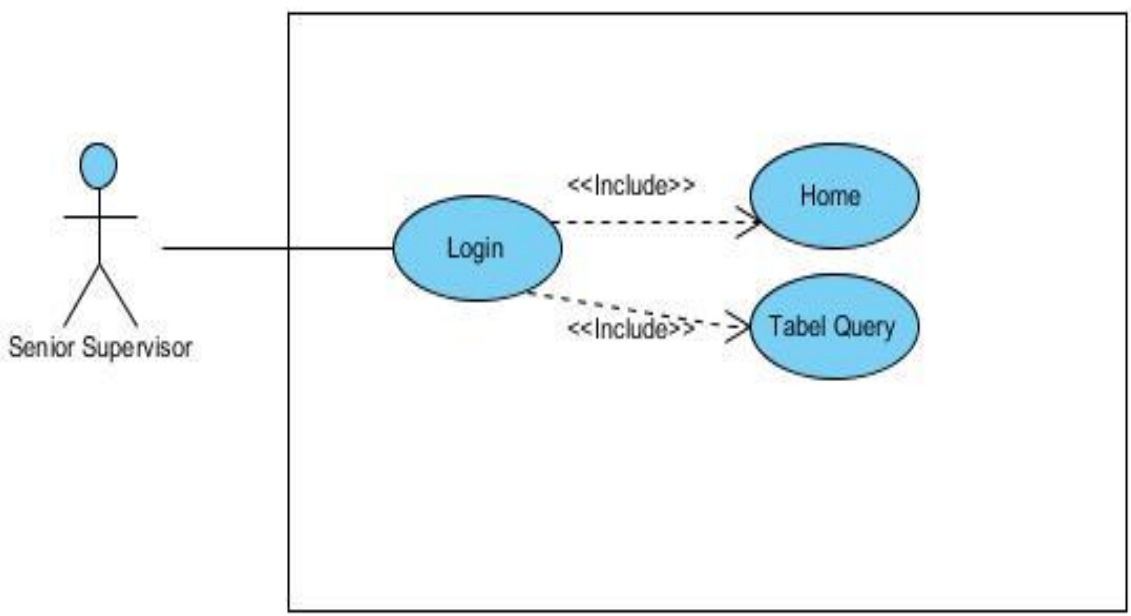

Gambar 2. Squence Diagram Login Senior Supervisor 
Unitek : Jurnal Universal Teknologi

Vol.14 No.2 Juli - Desember 2021

e-ISSN : 2580-2582, p-ISSN: 2089-3957

\section{b. Activity Diagram}

\section{Menu Login}

Aktifitas login menggambarkan kejadian pada saat pengguna melakukan proses login untuk memulai menggunakan sistem. Aktifitas login dimulai dengan memasukkan username dan password oleh user. Nantinya username dan password tersebut akan di cek validitas oleh sistem. Jika valid maka proses bisa dilanjutkan sedangkan jika tidak valid maka sistem akan meminta user untuk memasukkan kembali username dan password seperti yang terlihat pada gambar berikut:

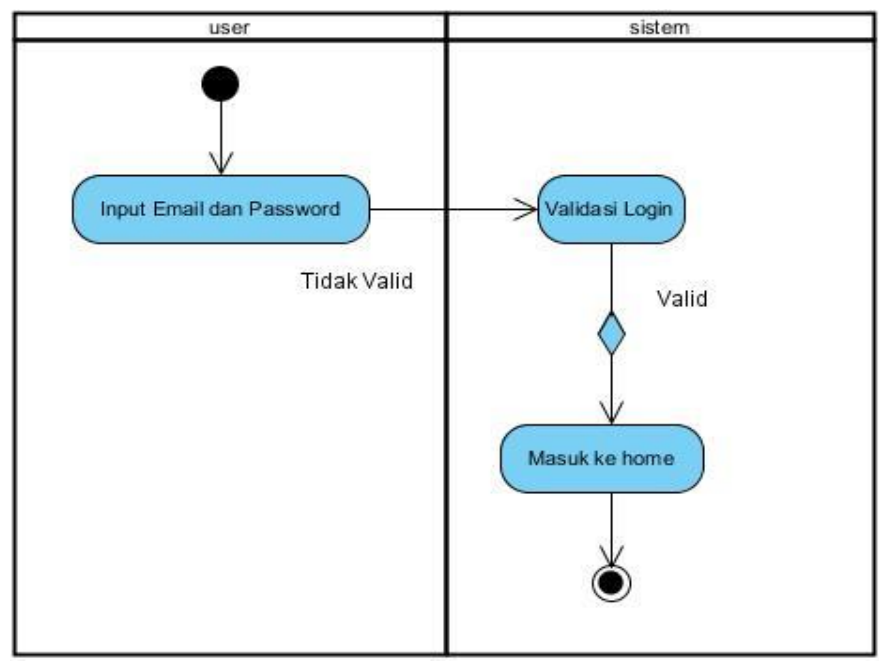

Gambar 3. Activity Diagram Menu Login

2. Activity Diagram Buat Laporan

Aktifitas ini menggambarkan proses dalam pembuatan laporan operasional. Setelah user berhasil login maka user akan masuk ketampilan utama (home). Lalu user akan memilih halaman buat laporan. Pada halaman tesebut akan menampilkan form laporan yang nantinya user akan menginput data yang ingin dimasukkan. Activity Diagram buat laporan meliputi Activity Diagram buat laporan Demineralizer, Activity Diagram buat laporan Boiler Stork, Activity Diagram buat laporan Boiler Mitsubishi, Activity Diagram buat laporan Fuel, dan Activity Diagram buat laporan Maintenance. Untuk lebih jelasnya dapat dilihat pada gambar sebagai berikut : 
Unitek : Jurnal Universal Teknologi

Vol.14 No.2 Juli - Desember 2021

e-ISSN : 2580-2582, p-ISSN: 2089-3957

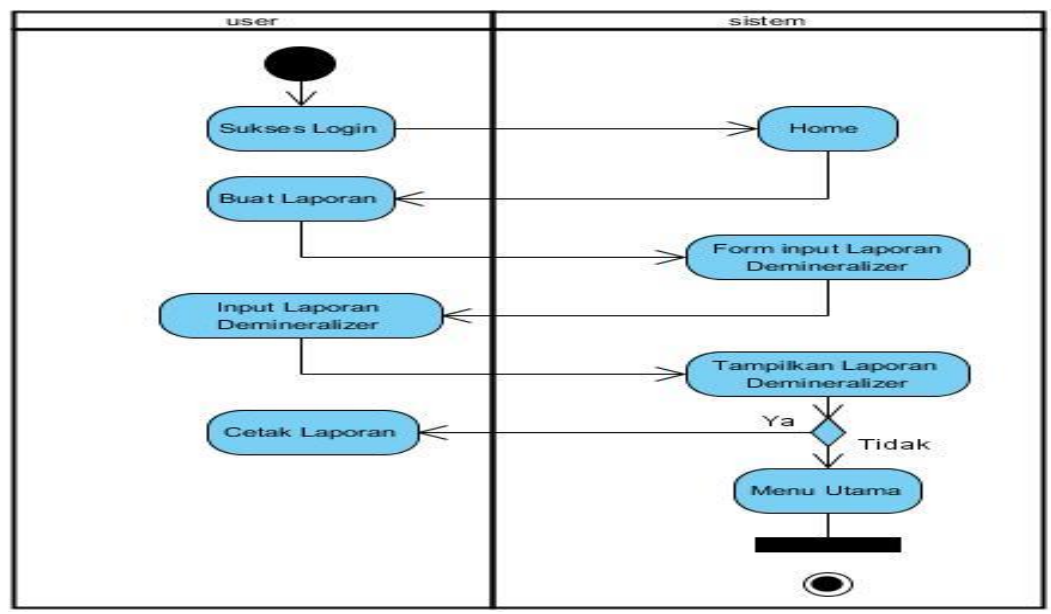

Gambar 4. Activity Diagram Buat Laporan Demineralizer

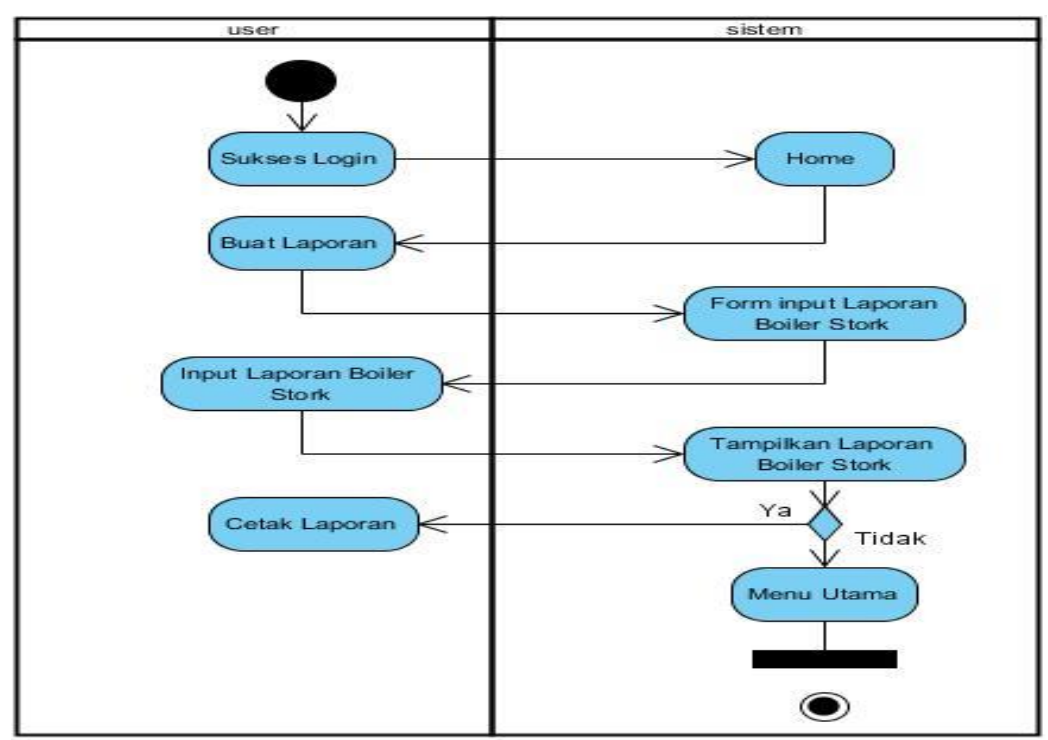

Gambar 5. Activity Diagram Buat Laporan Boiler Stork

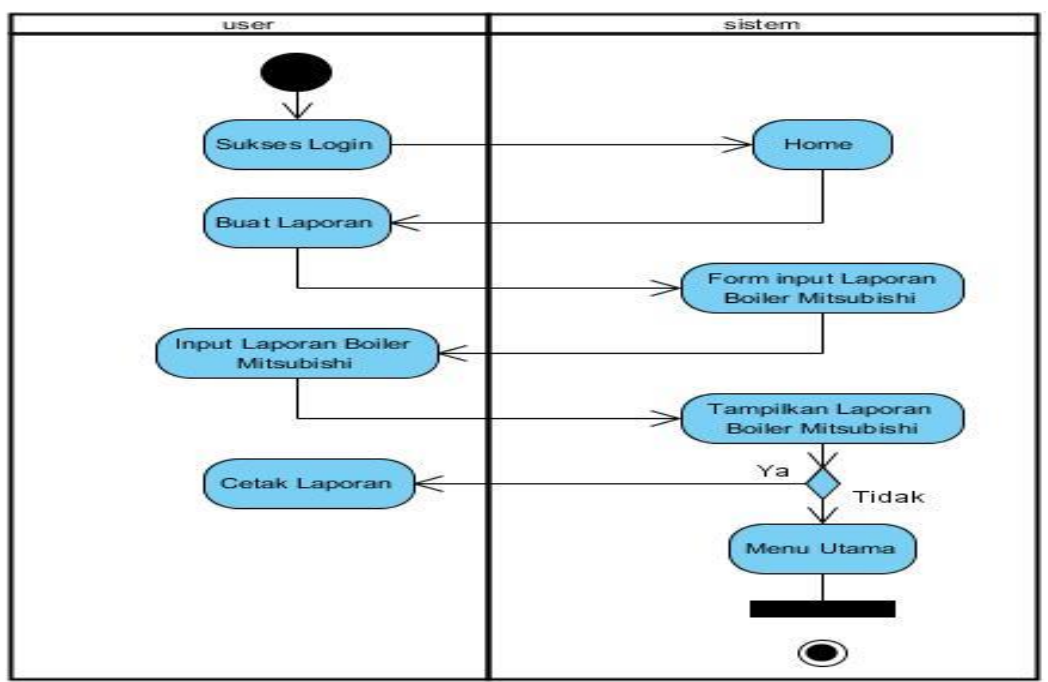

Gambar 6. Activity Diagram Buat Laporan Boiler Mitsubishi 
Unitek : Jurnal Universal Teknologi

Vol.14 No.2 Juli - Desember 2021

e-ISSN : 2580-2582, p-ISSN: 2089-3957

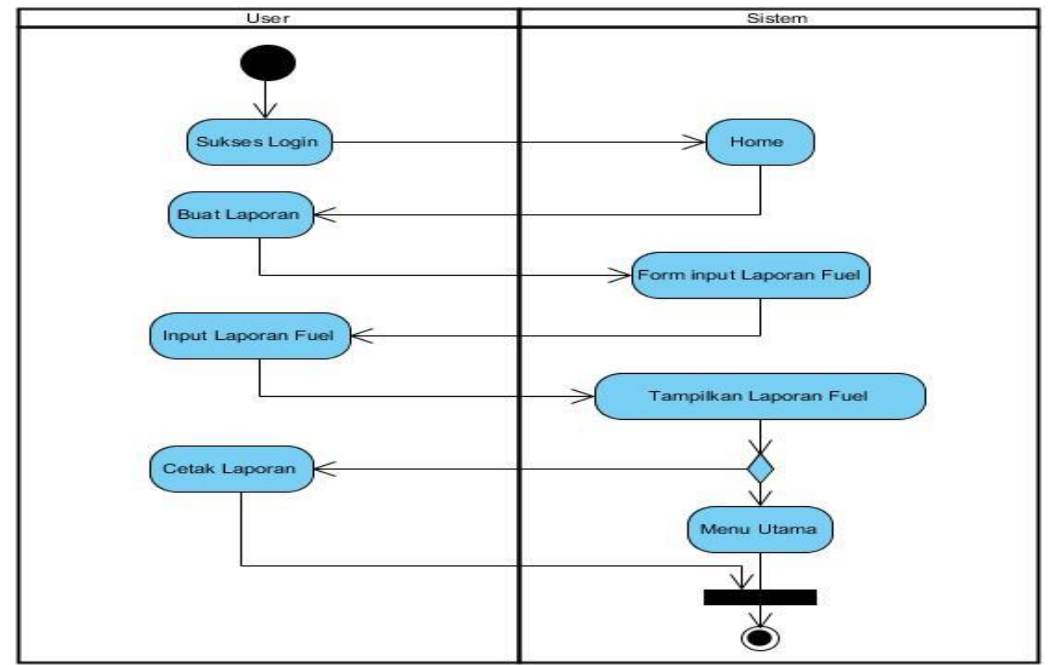

Gambar 7. Activity Diagram Buat Laporan Fuel

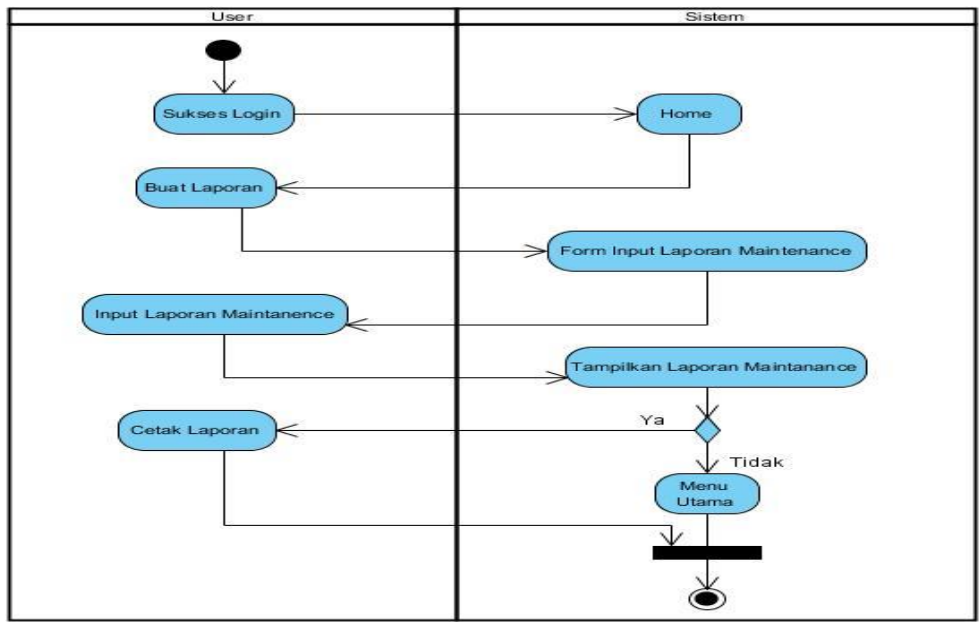

Gambar 8. Activity Diagram Buat Laporan Maintenance

\section{c. Squence Diagram}

Sequence Diagram digunakan untuk menggambarkan skenario atau rangkaian langkah - langkah yang dilakukan sebagai sebuah respon dari suatu kejadian/even untuk menghasilkan output tertentu seperti gambar dibawah ini : 
Unitek : Jurnal Universal Teknologi

Vol.14 No.2 Juli - Desember 2021

e-ISSN : 2580-2582, p-ISSN: 2089-3957

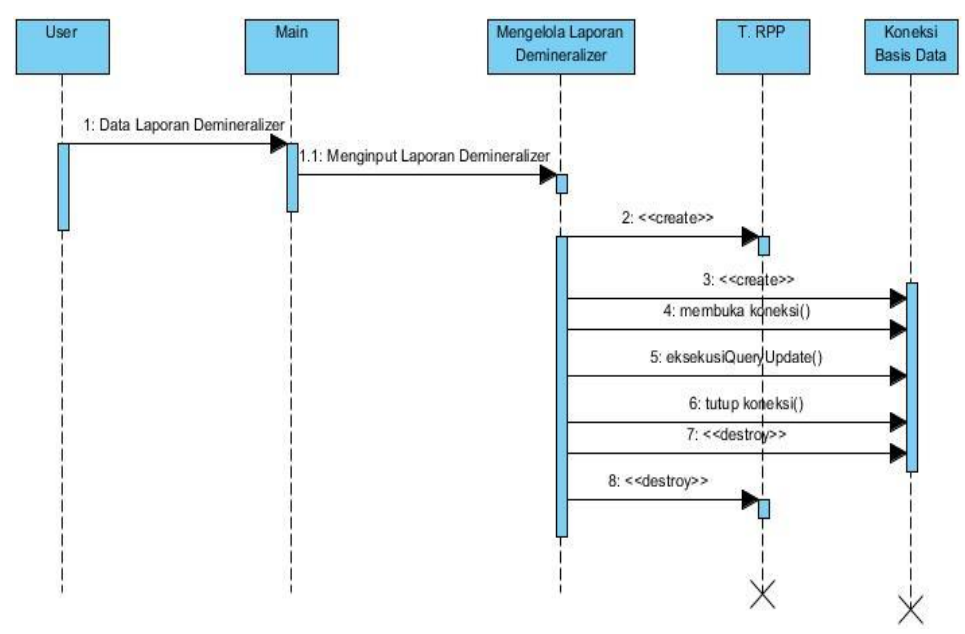

Gambar 9. Squence Diagram Input Laporan Demineralizer

\section{d. Class Diagram}

Bagan rancang diagram yang sesuai dengan database yang digunakan dapat dilihat pada gambar berikut :

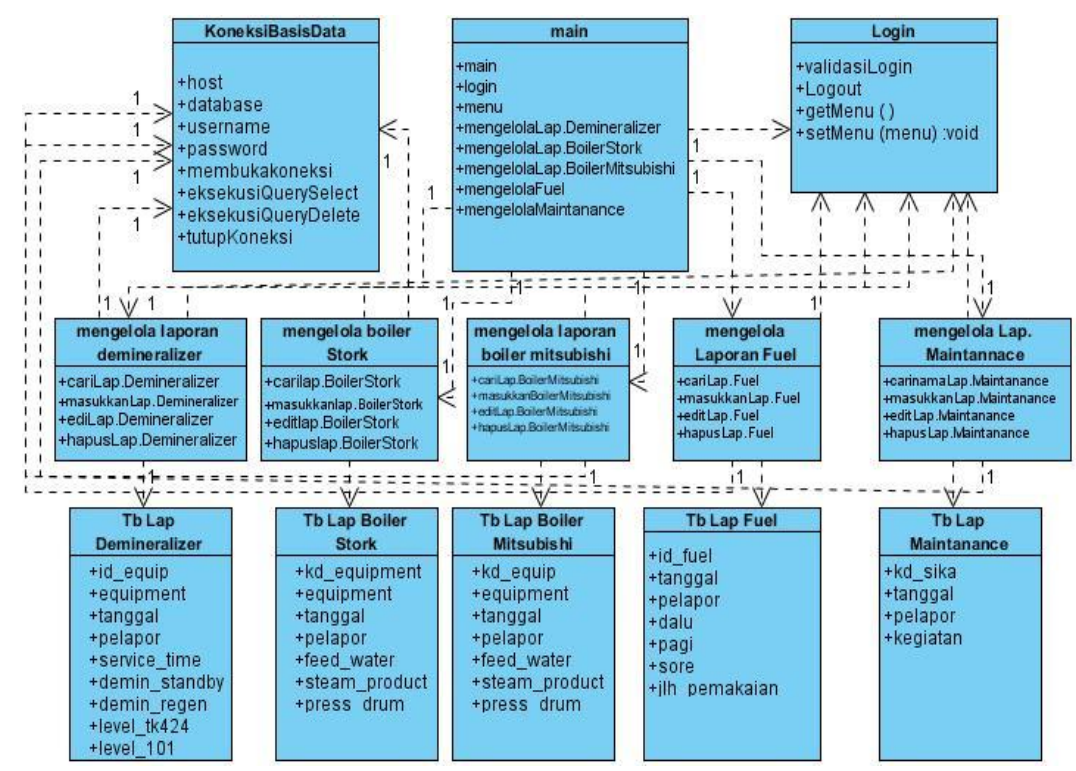

Gambar 10. Class Diagram

\section{Implementasi Sistem}

Sistem ini dibuat agar lebih efesien dalam penyampaian laporan operasional yang akan disampaikan kepada pimpinan yang dulunya masih manual, sehingga tidak efisien. Oleh karena itu Sistem ini dibangun untuk mempermudah dalam proses penyampaian kondisi operasional.

a. Halaman Login

Halaman login admin atau karyawan sebagai akses masuk kedalam Sistem dengan memasukkan username dan password yang benar. Berikut contoh halaman Login : 
Unitek : Jurnal Universal Teknologi

Vol.14 No.2 Juli - Desember 2021

e-ISSN : 2580-2582, p-ISSN: 2089-3957

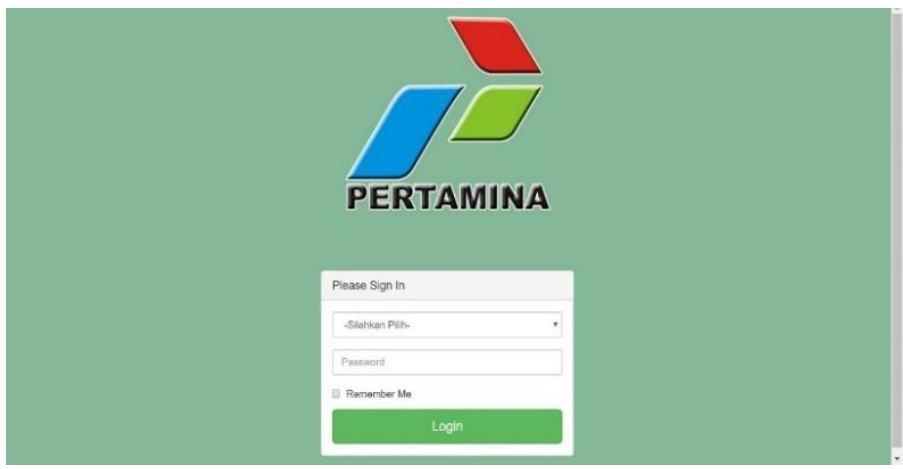

Gambar 11. Halaman Login

b. Halaman Shift Supervisor

Bila sudah berhasil melakukan menu login, maka akan masuk ke menu utama Shift Supervisor.

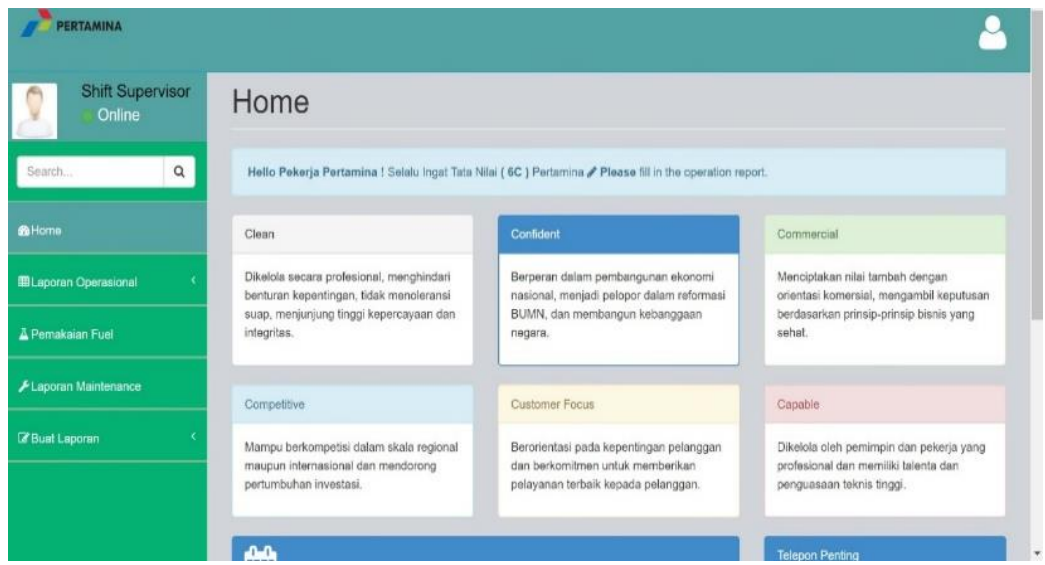

Gambar 12. Halaman Utama Shift Supervisor

c. Halaman Senior Supervisor

Bila sudah berhasil melakukan menu login, maka akan masuk ke menu utama Shift Supervisor.

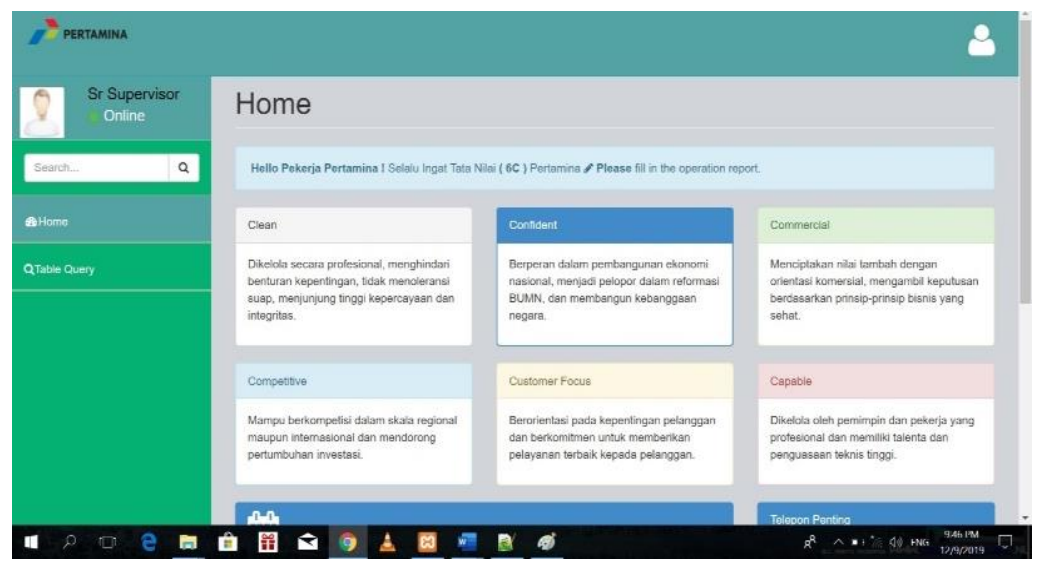

Gambar 13. Halaman Utama Shift Supervisor 


\section{Simpulan}

Dari Analisa yang dilakukan terhadap E-Report Utilities Shift Supervisor, maka penulis mengambil kesimpulan sebagai berikut :

1. Dengan adanya E-Report ini maka akan lebih memudahkan Shift Supervisor dalam membuat Laporan Operasional Utilities sehingga mampu meningkatkan kinerja operasional di lingkungan Perusahaan.

2. E-Report Utilities Shift Supervisor ini dapat menyajikan laporan operasional dengan lebih efektif, efisien dan tepat waktu. Sehingga upaya dalam mengetahui dan menanggapi laporan operasional dapat lebih optimal.

\section{Daftar Pustaka}

Caesar, A., Hanif, M., \& Pakereng, M. A. I. (2021). Pengembangan Aplikasi Sistem Informasi Operasional Bus Berbasis Web Menggunakan Framework Laravel, 8(3), 1027-1039.

Gatam, K. (2015). Sistem Informasi E-Document Korespodensi Pada Korem 043 / Gatam, 1(2), 15-18.

Hakim, I. L., Fitriani, L., Algoritma, J., Tinggi, S., \& Garut, T. (2013). Perancangan Sistem Informasi Laporan Surat Di Unit Pelayanan Teknis Dinas Pendidikan, 239-245.

Khairatunnisa, K., \& Sari, F. (2021). Sistem Informasi Donor Darah Pada Unit Tranfusi Darah (UTD) Palang Merah Indonesia Kota Dumai Berbasis Website. JURNAL UNITEK, 14 (1), 30-37. https://doi.org/ 10.52072/ unitek. v14i1.173

Mambu, O. E., Informatika, T., Sam, U., \& Manado, R. (2016). Pengembangan engembangan Aplikasi E-Report Layanan ayanan Masyarakat asyarakat untuk Manado Smart City, 8(1).

Rachmawati, S., Retnasari, T., \& Rachmawati, S. (2018). Optimalisasi Sistem Informasi Perjalanan Dinas Dalam Meningkatkan Efisiensi Biaya Perusahaan, $1,241-249$.

Rahardja, U., Aini, Q., \& Enay, N. (2017). Optimalisasi Dashboard pada Sistem Penilaian Ujian Mahasiswa Sebagai Media Informasi Perguruan Tinggi Optimizing Dashboard on Assessment System As An Information Media in Higher Education, 7(2), 167-176.

Sadharma, D. E. (2021). Design of Asset Collection Information System Based on Website, 1(April), 21-33.

Urva, G., \& Manalu, T. W. (2021). Aplikasi Pengarsipan Shipper Barang pada Counter JNE Bukit Kapur, 14(1), 2580-2582.

Urva, G., \& Sellyana, A. (2018). Aplikasi Penentuan Beban Sks Mengajar Dosen Pengampu Mata Kuliah, 11(2), 144-154. 